\title{
Rethinking natural resource management in Thailand
}

\author{
Mogens Buch-Hansen ${ }^{1}$ \\ Department of Society and Globalisation, Roskilde University, Denmark \\ Peter Oksen \\ Department of Society and Globalisation, Roskilde University, Denmark \\ Sidthinat Prabudhanitisarn \\ Faculty of Social Science, University of Chiang Mai, Thailand
}

\section{Socio-political change and altered perceptions of natural resources management in Thailand}

The global 'development epoch' began with an emphasis on formal development planning in the 1950s, and it ended with the onset of neo-liberalism in the 1980s, under the political leadership of Thatcher and Reagan. It corresponds to what the World Bank calls the "second phase" of globalisation (World Bank, 2002), which were experienced in Thailand and other countries in South-East Asia. During Thailand's thirty-year "development epoch", commercial agricultural development became the backbone of economic development. Specialised agricultural sciences, working in a variety of institutions across Asia, developed widely-disseminated "Green Revolution" technologies, and growth in the agricultural sector helped lay the groundwork for the subsequent boom in export-oriented manufacturing that led economic growth from the mid-1980s.

It is our aim in this article to illustrate how perceptions of environmental changes and environmental problems in Thailand have been created and deployed in this socio-political context. We argue that agricultural environments and their management have become contested domains in contemporary Thailand, but often this contestation has occurred because of narrow positions corresponding to the academic disciplines. We explore an alternative, transdisciplinary approach to knowledge creation that is more akin to the current thinking on resource management offered by critical political ecologists. This approach was developed in SLUSE (Sustainable Land Use and Natural Resource Management), a collaboration among universities in Denmark and Thailand, and the approach it develops combines analysis with knowledge "creation".

When General Sarit took power in Thailand in 1958, he oriented the economy to export-led growth, and Thailand soon became the fifth biggest exporter of agricultural commodities among the developing countries. The agricultural sector was quick to adopt the technologies of the Green Revolution, and the driving force of many government agencies was to increase agricultural output. The vocabulary of Thai agriculture and natural resource management subsequently became dominated by Western rational thinking, and by a drive to higher levels of production that had much to do with post-War American-led modernism and its economic growth ethic.

This major change in national economic orientation was written on the landscape. The development discourse under authoritarian military rule during the 1960s and 1970s (paused by the students' revolt and political turbulence from 1973 to 1976) had real effects, transforming the major part of Thailand's forests to arable land. Linked to this, the number of small-scale land holdings doubled from the late 1950s to the mid-1980s (Phongpaichit and Baker, 1999). Since this time there has been an ongoing struggle between smallholder communities that are attempting to continue their livelihood practices in an era where export agriculture has now become less important to the national economy, and the efforts of the Royal Forest Department (RFD) that is trying to control access to the remaining, unconverted forests and asserts the rights to manage them. A prominent part of this struggle is a twenty-year old debate over the Community Forestry Bill. At the centre of this struggle are contested definitions of natural resources - of forest and forest cover, as well as differing views over the sustainability of community forestry, shifting agriculture, and other traditional farming practices.

The RFD has been claiming that the local communities living within the forest reserves have been depleting forest resources by pursuing their traditional farming practices. In many parts of the country, however, the right to livelihood of forest communities has also been asserted as a counter-narrative, and it has received support from non-governmental organizations, who challenge the right of the RFD to

1 Department of Society and Globalisation, Roskilde University, P.O. Box 260, DK-4000 Roskilde, Denmark. Email: $\underline{\text { mobh "at" ruc.dk }}$ 
control forest access in an authoritarian fashion. The struggle results, in part, from differing environmental epistemologies that play out within a changing socio-political framework (Forsyth, 2003). Environmental knowledge in the RFD and among the local communities is based on conflicting concepts of environmental change and management.

\section{A growing civil society and a changing social framing of environmental knowledge}

As export-oriented manufacturing sector took the lead in Thailand's economic development from the 1980s, there was also a rapid growth in volume and strength of Thai civil society. ${ }^{2}$ Civil society now included a growing number of NGOs with diverse mandates and orientations, with many pushing for a more sustainable utilisation of natural resources. In the absence of formal political parties representing the full range of socio-economic and ideological differences, it was the NGO movement that played the role of pushing for political empowerment from below, taking on an advocacy role and asserting communities' rights over local natural resources (Dechalert 1999, Thabchumpon, 2002).

Economic growth resulted in rapid resource depletion through the conversion of tropical forest to agricultural land without proper maintenance of soil properties or bio-diversity. Thailand's manufacturing industry grew without much consideration of the impacts of air, soil and water pollution. The response from the NGO community was a call for reform of the highly centralised Thai bureaucracy that had manifestly failed to regulate these impacts, arguing for decentralisation and devolution of state power. These demands were eventually reflected in the 1997 Constitution, and the $8^{\text {th }}$ and $9^{\text {th }}$ National Economic and Social Development Plans. A specific demand in the 1990s was that $20 \%$ of Thailand's agricultural land should be converted to sustainable modes of agricultural production. Although this issue is very central to the $8^{\text {th }}$ Economic and Social Development Plan (1997-2002), there is little evidence on the ground that this goal will be met. ${ }^{3}$

The past two decades have seen many controversies over access to and utilisation of natural resources, such as the Pak Mun dam controversy over electricity generation, which threatens fish breeding, low-lying river islands, and other natural resources supporting local livelihoods. Pak Mun was completed in 1994 by the Electricity Generating Authority of Thailand, with World Bank financing. Since 1990 it has resulted in intense opposition by local communities. Some 20,000 people have been affected by drastic reductions in fish populations that can no longer migrate upstream of the dam site. The International Rivers Network and the Assembly of the Poor are two NGOs supporting dam decommissioning; the AOP was formed in 1995 specifically to oppose mega-development projects of this type. In 1999, more than 5,000 villagers occupied the dam site and established a protest village. The government agreed to open the dam gates in June 2001 while studies were conducted on fisheries, social impacts and the impact of the dam on Thailand's electricity supply. The government rejected these studies that were favorable to the local villagers' case, and it allowed only a four month opening each year, closing the gates again in 2002 (IRN 2002).

Similarly, the RFD has been struggling with local communities for decades over eucalyptus plantations that supply the paper industry and ostensibly maintain "forest cover". Having encouraged logging and clearing of forest areas that were believed to be hiding communist insurgents in the 1970s and 1980s, new local settlers were permitted to occupy the cleared land for a time, before being forcibly removed after 1991, under the state-supported drive to create industrial eucalyptus plantations. Local communities often claim that these plantations drain the soils of water and nutrients, while depriving them of pasture and forest resources. Although the eucalyptus boom has now peaked, substantial plantations still exist and opposition to them continues (Carrere and Lohmann 1996, Dechalert 1999).

These two examples illustrate how the state tends to adopt the utilitarian values of neo-liberal development theory, only changing course - if at all - after substantial opposition to its policies. It is somewhat inevitable that locally grounded NGOs and communities themselves have arisen to challenge technocratic development schemes that transfer benefits to industry, urban dwellers, or the state - and they see their exclusion from such projects as symptomatic of a lack of concern for local environmental resources. The NGOs have, in the language of critical political ecology, "co-produced" environmental knowledge and political activism at the same time (Forsyth, 2003), forming what Bryant (1997) calls a 'counter-coalition' of potentially like-minded actors comprising farmers, environmental NGOs, researchers, journalists and sympathetic governments and UN agencies. Today these form the basis for a number of alternative environmental movements concerned with justice and livelihoods.

\footnotetext{
2 See Hirsch (1996a) and the collection of articles in Hirsch (1996b).

3 For an analysis of sustainable agriculture in the Thai context see Buch-Hansen (2001).
} 
Tim Forsyth directs our attention to the "social framings" of environmental science and knowledge that colour such disputes, arguing that environmental knowledge can be democratised through problemoriented, interdisciplinary and participatory approaches to the analysis of environmental issues (Forsyth, 2003). We will now look at how this has worked in Thailand: environmental problems have been narrowly defined by conventional science, but a broader understanding of environmental problems and their solutions based on an interdisciplinary, context-dependent approach may yield more satisfactory social and environmental outcomes.

\section{Dominance of compartmentalised scientific knowledge in the $20^{\text {th }}$ century}

By and large, the existing knowledge explaining how natural resources in Thailand have been degraded is clustered around two approaches. Natural scientific disciplines have investigated the changes in natural ecological systems while social science analyses have looked at the causes and effects of production, livelihoods, and socio-cultural-ecological systems. We have been provided with a huge pool of scientific research that essentially describes changes in natural resources and biophysical causes and effects. Research has demonstrated that large areas of forest are replaced by highland and upland agriculture that has implications for ecological systems: this is well documented (Chuntanaparb, 1986; Feeny, 1988; Gardner, 2000; Samapuddi, 1962). Hydrological changes have simultaneously occurred, evident in irregular rainfall, floods, and droughts (Preechapanya, 1984). It is also reported that the degree of soil erosion, sedimentation, weed infestation and degradation of natural resources have become more serious over time. Thailand seems to have experienced a continued decrease in biological diversity (in terms of species, genetic pools and ecosystems of flora and fauna of tropical forests). The genetic pool of the tropical zone has also diminished, and there are adverse climatic changes caused by a decrease in moisture and forest cover (Collins and Qualset, 1998; Somsak Sukawong, 2003; Tisdell, 1997).

Endangered tree and animal species have been studied by scientists in order to target their regeneration more effectively (Anderson, 1993; Holmberg, 1996; Sukawong, 2003). Soil scientists are able to explain physical and chemical processes of different soil types and they can establish indicators of soil quality and nutrients (Bunchee, 1993; Preechapanya, 1984; Putjaroon, 1987; Samran, 1984). Hydrologists explain and measure physical, chemical, and biological water contamination (Suksawang, 1991; Walker and Scoccimarro, 2001). Thailand has produced many inventories of biophysical degradation of resources. Scientists are able to apply their knowledge by offering technical solutions to technical problems of forest, land, and water. But the relationship between human utilisation of natural resources and natural resource degradation is still poorly understood in the scientific world, and understanding of the complex relationship between environmental changes and their social, economic, cultural, and political contexts is poor.

By contrast, explanations of degradation by social scientists have, so far, focused mainly on exactly how such perceptions of causes and effects become universally adopted and deployed. ${ }^{4}$ Attempts have also been made in anthropology, sociology, political science, economics, psychology, and human geography to question how human activities are related to natural resources. Knowledge from the social sciences is vital to understand social and economic processes, but developed in isolation, the whole range of social and environmental impacts can be scanted, and narrow analysis can end up justifying dams or plantations on grounds of utility and cost return alone. Social science knowledge in Thailand has developed in large measure from Western epistemological foundations with a specialised division of labour between the disciplines (Ganjanapan 2000; Santasombat and Siamwala, 1998). Therefore, each set of explanations has its own paradigm and there is disputation around whose reality is more valid and powerful; it is inevitable that policy makers favour some paradigms over others, with economics and political science emerging as dominant in the Thai case (Benton and Craib, 2001). Thai social science has not provided applicable solutions to the variety of problems concerning natural resource utilisation and management. ${ }^{5}$

4 Many of these macro-ecological myths, or what Tim Forsyth calls environmental orthodoxies, stem from the popular equation I=PAT, which asserts that the environmental impacts (I) are consequences of population growth (P), rate of consumption in the society (A) and technological innovations (T). Applied to tropical deforestation, $\mathrm{P}$ is population pressure resulting in expansion of agricultural land or shifting cultivation. Similar myths seem to repeat popular beliefs concerning watershed degradation, desertification, deforestation etc. found elsewhere (Forsyth, 2003).

An exception was a series of projects initiated by Khon Kaen University in Northeast Thailand during the late 1970s and 1980s. These were interdisciplinary in nature, but were not sustained after the Ford Foundation withdrew funding. The Social Research Institute at Chiang Mai University was also involved in participatory research into forest management in the 1990s (Zurcher, 2005). 
Since the 1980s a number of studies have questioned whether the degradation of natural resources can really be explained by accusations of ignorance or irrational farming practices on the part of rural people, or by the single variable of population growth. Rather, it is argued, problems stem from government laws and policies as well as economic development forces - these increase the pressure on the cash economy to provide livelihoods, and also limit people's rights and access to natural resources (Lohmann, 1998; Panayotou and Parasuk, 1990). Rationalist policy making, use of the newest agricultural technologies, and the absorption of surplus rural labor by the new industries seems to have worsened inequalities and depleted resources. Critics also point to the failure of national economic development plans to meet their targets. While Thailand has experienced rapid economic growth in Bangkok and other urban areas it has also seen worsening income inequality, more landless people, further agricultural expansion at the expense of forests, and localised land degradation.

For political economists, it is the linkage between the Thai state and the forces of capital that underlie these problems. State and capital have expanded their control over production and resource utilisation, seeking a 'spatial fix' by moving from core to peripheral regions. Economic development and the modernisation process has changed people's mode of production, consumption, and livelihood, and set up relations of production where the state and capitalists transfer an economic surplus from farmers and rural areas to industrial and commercial activities in Bangkok and other major trading centres. Due to the historical dominance of middlemen and (in recent years) the agribusiness companies, farmers have limited access to means of production and markets and subsequently become increasingly dependent on off-farm activities, and more consumerist in their behavior. The enclosure of forest reserves has pitted local communities and increasingly militant NGOs against government agencies and capitalist enterprises. While local communities claim their rights to practice traditional farming methods to sustain their livelihoods, the commercial farmers, agribusiness companies and recreational managers (some of them high-profile), all supported by government agencies, claim their legal right to economic development and exclusionary leisure and conservation uses (see Ganjanapan et al., 1993; Bryant, 1992; Ganjanapan, 1996; Hirsch, 1993; Lohmann, 1998; Sato, 1998; Vandergeest, 1996).

\section{The search for knowledge that captures the complexity, diversity and dynamism of natural resource management}

And, yet, there is a wealth of existing knowledge about natural resource utilisation in Thailand most of it consists of biophysical inventories - but knowledge nonetheless. While Thailand is now in an economic transition that is seeing it emerge as an important regional powerhouse, it is seeing more and more conflicts over this development trajectory - perhaps because there is now so much to "oppose".

Academics have produced most of the formal knowledge used to drive this opposition, and holistic thinking on these questions is rare - the totality of a complex problem with diverse interconnected components has been disassembled into analytically digestible components by the practitioners of the disciplines. By contrast the stakeholders who are closest to forest, marine, and agricultural resources, land users themselves, have seldom participated in developing agendas or have only been permitted to apply their pragmatic skills. Thailand has, we argue, reached an impasse in managing knowledge effectively (Bryant, 1997; Rigg, 1995), despite the presence of some bold but short-lived experiments (Zurcher, 2005). Therefore, what the nation needs in the present phase of bureaucratic reforms, in addition to these in-depth specialised and universal pools of knowledge, is a pragmatic, context specific, and problemsolution driven knowledge. A kind of knowledge that is being created, recreated, and applied to effective solutions to social conflicts and possible exploitation of natural resources, all of which undertaken with the participation of stakeholders. Not just an interdisciplinary approach, but an approach that identifies problems, analyse them holistically and systematically by participating stakeholders, and that incorporates relevant disciplinary knowledge - what O'Riordan calls transdisciplinary knowledge creation (O'Riordan, 2000).

As a part of this, it is desirable for scientists to place additional focus on providing evidence of the relationship between environmental changes and perceptions ('local knowledge') of environmental problems. Indicators for monitoring changes of natural ecology that have a positive or negative impact on human society may illustrate that ecological equilibrium is not necessarily a natural state, even within the remaining forest reserves. If the ecology is constantly changing in dynamic relationship with the human uses of it, then it is social perceptions that determine the point at which a change becomes an environmental problem. A beautiful flower in the wrong place is a weed! Democratizing the range of perceptions that are taken into account when making land use decisions would reduce the potential for resource conflicts. 
In the social sciences, the social deconstruction of 'problems' traces them to their root causes and further exposes the diversity of knowledge about them. People from different social, cultural and political contexts need to understand themselves, other stakeholders, and the dynamic interrelationships between livelihoods and natural resources. Self-awareness or self-actualization may be mediated through academic or analytical interpretation. Self-directed knowledge is not scientific in the conventional sense of the term, but it is 'grounded' and appropriate in context.

As we illustrate, academic knowledge systems can play their part in creating liberatory knowledge, awareness, and action. This must occur at different scales and at different points on the explanatory 'chain' that political ecologists employ. Among the stakeholders are different groups of villagers with different interests, local governments now being strengthened through the process of decentralisation and devolution of power, district and provincial agencies, non-government organisations, and academics and researchers. An innovative approach to knowledge creation and learning can help mediate between different stakeholders who have different interests, and thus help to construct different concepts and perceptions (Fischer, 2001, Zurcher, 2005).

The following section illustrates how such a holistic, interdisciplinary and participatory approach to understanding the relationship between environmental changes and socio-economic development could be applied to the problem of creating more sustainable agricultural practices in Thailand.

\section{The enhancement of knowledge for sustainable agriculture}

According to an official publication of the Thai Ministry of Agriculture and Co-operatives (MoAC), the rapid increase in agricultural production and arable land has resulted in soil loss of approximately 120 tons of soil per hectare annually from most severely affected cultivated, deforested upland areas. This erosion has caused heavy siltation in water reservoirs and sedimentation along rivers. Significant quantities of soil and plant nutrients are leached by water run-off, estimated in a total nutrient loss of 27.4 million tons per year. The Land Development Department estimates that 19.4 million hectares of soil are prone to salinization, while saline soils already cover some 0.56 million hectares, and acid sulfate soils 0.14 million hectares (Ministry of Agriculture \& Co-operatives, 2002, p3) The report does not even include the further problem of water shortages or the pollution of waterways from overuse of agrochemicals and contamination of irrigation water by shrimp farming.

These problems have all been analysed and described by natural scientists from a number of research institutions and government agencies, without getting to the root of the problem. This is considered outside the scientists' sphere of competence. An advisor to the Office of the Permanent Secretary in the MoAC describes how the physical manifestations of ecological problems have placed emphasis on technical modes of analysis:

Although the manifestation of land degradation is primarily physical, it is in fact, the physical outcome that results from a biophysical condition, which, in turn, is driven by socio-economic and political processes. (Nabangchang, 2001, p12)

The outcome has been to place the entire emphasis on technical solutions to address environmental problems associated with land degradation at the risk of ignoring a range of other socio-economic and institutional variables that determine the different land use practices. (Nabangchang, 2001, p18)

The national Thai Development Plans, from the first in 1960 to the seventh (1992-96) were very growth-oriented (Kittampon and Nabangchang, 2001: 2). Macro-economic policies set the framework for agricultural policies that, with the support of forces favoring market growth, pushed for increase of production with little or no consideration for the natural environmental. These policies (e.g. a rice premium export tax) also transferred the economic surplus from the agricultural production and accumulated it in Bangkok and the trading centres. Rural farmers generally remained politically subdued. ${ }^{6}$

Although Gross Domestic Product (GDP) increased by almost 10\% annually during the boom years from 1985 to 1997, the distribution was extremely biased with the top 20\% of the population sharing

$6 \quad$ For an introduction to the role of agriculture during the development epoch see Buch-Hansen (2003), Dixon (1999), Falvey (2000), Muscat (1994), and Phongpaichit \& Baker (1999). 
$58.5 \%$ of GDP in 1999 , while the poorest $20 \%$ had only $3.8 \%$. The poor remain predominantly rural, especially in the Northeast. The riches members of society cluster in Bangkok and have a per capita income 12 times higher that the Northeast. Conventional agriculture in the region has pushed farmers to invest in new technologies with the result that many of them have become seriously indebted. The number of indebted households increased from 1.3 million in 1976 to 2.9 million in 1996 (Ministry of Agriculture \& Co-operatives, 2002: 4). This was forcefully stated by the Deputy Permanent Secretary to MoAC:

The agricultural sector is heading to a crossroad where decisive changes must be undertaken for the survival of the economy, the environment and the producers themselves. (Kittampon and Nabangchang, 2001: 5).

Yet alternatives are not easily defined. In the Thai context, the concept of sustainable agriculture has been used with a great deal of ambiguity (Buch-Hansen, 2001). The Ministry of Agriculture and Co-operatives offers a very pragmatic definition based on a lack of nutrient depletion (Ministry of Agriculture \& Cooperatives, 2002: 6). Yet sustainable agriculture is not widely practiced or understood, since as the Ministry says:

Both formal and informal education programs have neglected the importance of sustainable agriculture. Sustainable agricultural development must begin with the understanding, knowledge, attitude and awareness of the importance of sustainable agriculture for the individual, household, community and society. (Ministry of Agriculture \& Co-operatives, 2002: 22).

While conventional top-down learning processes to impart specialised technical knowledge are appropriate to direct conventional agriculture, sustainable agriculture requires alternative learning processes. It needs the holistic approach we have already referred to, in which agricultural production is seen in the context of community development, a long time frame, and livelihood self-sufficiency. This requires that the farmers and the government agencies learn how to work in groups and networks and experiment with farming practices and off-farm activities that enhance short-term economic viability, while being acceptable to local people and retaining natural capital for the future. The task is clearly one for trandisciplinary thinking and the joint formulation of new ideas and knowledge. Natural scientists can analyse the biophysical processes creating environmental changes. Working together with social scientists they can get to the root causes of environmental changes and also establish what is perceived as an environmental problem. An advisor to the MoAC expressed this in terms that are rather too utilitarian perhaps, but show some comprehension of the potential for new ways of thinking:

The major challenges, which require collaboration between natural and social scientists, are to determine the carrying capacity of the natural ecosystem and to determine the complexities between society and the natural ecosystem. The natural scientists and social sciences need to collaborate to bridge the gaps between biophysical and social sciences (Nabangchang, 2001).

Can it be done?

\section{A transdisciplinary approach to NRM}

The Sustainable Land Use and Natural Resource Management Programme (SLUSE) is an interdisciplinary and problem based educational and research programme among collaborating universities in Denmark, Thailand, Malaysia, South Africa, Botswana and Swaziland. ${ }^{7}$ In Thailand the SLUSE programme has been working with three Thai universities and RFD since 1997, in a program called TUCED-SLUSE. ${ }^{8}$ Under the SLUSE program, research has been carried out in Northern Thailand that seeks to overcome the distance between biophysical and social sciences by applying an alternative interdisciplinary approach. A pilot research project was initiated in the Song Watershed in Phrae Province

7 For further information on the programme, see www.sluse.dk.

8 TUCED stands for Thai University Consortium for Environment and Development. 
in 2001, involving additional collaboration with the University of Malaysia Sarawak (UNIMAS) (see Traynor et al., 2002). Previous to this, Danish and Thai Masters students had been conducting joint field courses in the watershed since 1998. Joint field courses have later been carried out in Khun Samun watershed in the neighbouring Nan Province, where a joint Thai/Danish problem-based and interdisciplinary research project began in 2003.

These research projects bring together an international group of researchers from different disciplines and institutions, working together on a common theme. The teams are divided into specialised mono-disciplinary working groups in order to allow for in-depth studies that require specialised knowledge and skills. However, the research design, including the choice of a common pool of respondents, and the results, are synthesised across these working teams in order to allow for a richer understanding of the complex relationships between livelihoods and natural resources. Through this interdisciplinary or transdisciplinary research model, we think the double aim of creating in-depth specialised knowledge and comprehensive and holistic interdisciplinarity is best achieved.

The research has a broad scientific base and includes local actors, notably the RFD and other government agencies, and an NGO. In several cases research has been a direct result of the cooperation between different disciplines, and has revealed the full complexity of local land use.

The study location has been the Song watershed in the northern part of Phrae Province in Northern Thailand. Tho Saman village, located close to the lowland part of the Phrae valley is one among several villages utilising upland areas for economic activities. The Song River, a tributary to the Yom River, was dramatically changed when in 1993 a medium scale irrigation dam was constructed, creating a 420 ha reservoir. Characteristic of the land use in the watershed is irrigation of low lying fields alongside rainfed upland production, often on steep slopes. The major part of the uplands are in the National Reserved Forest Classification set aside for forest conservation, but as in many other parts of Northern Thailand, actual land use is often in contradiction to official land classifications. An important motivation for the research was to achieve a better and holistic understanding of the dynamics of the use of upland areas in conflict with official conservation policies.

Some of the findings were:

- The cultivation of distant and relatively low-potential rain fed upland fields was not associated with a distinct socio-economic stratification. It was expected that upland farmers would be relatively poor and forced to use land because of limited access to the valuable irrigated lowland fields. However, social and economic studies revealed that the economic potential of the upland fields was far from negligible, although significantly lower than for lowland irrigation. This potential allowed for well-off farmers to specialise in rain-fed agriculture and as such exploit its potential alongside a number of less well-off farmers.

- A particular individual, an entrepreneur and middleman, was discovered to be important for the exploitation of upland areas. He was an influential figure in the local community who had succeeded in establishing a monopoly of the sale of farm inputs and produce. Thus, land use was determined in part by a complex web of specialisation, economic strength and partly by historically determined power relations. Land use could not be explained by location, soil quality and socio-economic stratification alone.

- The creation of the reservoir by damming the river was instrumental for upland production. Access to the uplands was difficult even in the dry season, but the reservoir improved access considerably, so that milling machines and other equipment could now be sailed to the distant fields by boat, rapidly and at lower cost. Thus, the reservoir contributed not only to intensified exploitation of lowland areas though improved irrigation, but also to further exploitation of conservation zone areas in the uplands. A conservation buffer-zone around the reservoir created to protect it from erosion, was only effective in the close vicinity of the reservoir.

- Environmental degradation resulting from the cultivation of upland fields in the form of erosion and nutrient and pesticide release in waterways was relatively low. The science team could report that erosion levels were only critical in fields on very steep slopes, but also that farmers generally did not consider erosion to influence the productivity of the land and hence did not bother to introduce measures to reduce it. Generally, the water quality in the rivers and the reservoir was good, with limited downstream release of excess nutrients. However, persistent organochlorine pesticides (OCP's) were found in relatively high concentrations in the river and reservoir sediments, indicating that some adverse effects of upland cultivation did occur. 
- Often, secure tenure arrangements in the form of title deeds, are seen as a prerequisite for farmer's willingness to invest in land. It was found that there was no correlation between land use and tenure, and that land tenure in the uplands was controlled by unofficial rights in areas that were officially designated as forest reserves. Although these areas were cultivated illegally according to formal law, land was actually bought and sold despite the absence of formal land rights. Farmers did have a strong wish for proper officially recognised tenure arrangements, but their absence had very little, if any, influence on actual land use. Furthermore, farmers were able to obtain financial credit through informal arrangements or through group liability loans from agricultural banking institutions (BAAC) without having to produce a title deed as collateral. This practice, which is introduced by state-owned enterprises with the specific aim of improving farmers' access to credit, counteracts the official policy on forest conservation, as loans are not constrained to land officially approved for agricultural purposes through land titling.

An interdisciplinary approach proved indispensable for gathering and analysing a variety of information of this type, drawing at times on the specialised insight of experts. Compiling this information into a holistic understanding of the complex relationships in a village environment was a rewarding experience. It took place during a ten-day write-up workshop with participation of all the specialised research teams. Showing specialists with the findings of the other teams, led to fruitful discussions that effectively broke down some of the more simplified perceptions of the dynamics of upland farming. A community meeting was held, with the participation of local government agencies. The linkages revealed during the research were used as the point of departure for discussions of natural resource management and agricultural extension services. Although few tangible results could be observed from these discussions, the meeting did present local authorities as well as farmers with a holistic understanding of the issues that was new for many of the participants. For this to have tangible impacts of resource management, a long-term strategy must be adopted with a committed and active participation of state extension services and NGOs. The RFD's participation to date has been encouraging, since it appears to have been open and has shown interest in working with the local communities.

The Song Watershed pilot project, including the community meeting, cannot be enough to solve land use conflicts in the area, but it illustrated the importance of recognising that natural resource use and management is highly complex and cannot be reduced to the often simplified explanations provided by mono-disciplinary investigations. A transdisciplinary analysis, based on multiple sources of information, is really only the first step in identifying alternative solutions to natural resource management conflicts.

A further step is the educational programmes at the Thai universities involved in the TUCEDSLUSE programme. They are aimed at mid-career professionals, who will hopefully have greater scope for translating their knowledge into action. People already in influential positions in the government agencies and NGOs are absorbing and using new interdisciplinary knowledge.

Furthermore, by revealing how environmental perceptions have been framed according to different socio-political contexts, local communities are also in a better position to question the technical solutions proposed by government agencies and agribusiness companies. They understand more readily the risks of further resource depletion, and the reasons for their uncertain tenure in forest areas.

\section{Conclusions}

A process of political reform in Thailand began in the mid-1980s, and it is still far from complete. At the same time, export-oriented industrialisation has helped to make Thailand the fifth Asian Tiger economy. The foundation for this was the transformation of the Thai landscape, generally from a dense cover of tropical forest to rapidly expanding cultivated land with resultant environmental problems. It is not surprising that there are considerable differences in the perception and understanding of these fastchanging landscapes and the natural processes that sustain them. Critical political ecology enables us to pinpoint how socio-political and socio-economic change has "co-produced" the Thai landscape, and also driven significant resistance to some of these changes (Forsyth, 2003).

It is not enough to merely note that discourses and knowledge have become compartmentalized in the new Thai economy. The key is to move beyond mono-disciplinary thinking. The transformation of growth-oriented, conventional agriculture to sustainable agriculture is an illustrative case. The SLUSE approach to problem-oriented, participatory and interdisciplinary. Knowledge creation and dissemination in environmental management is an exercise in "knowledge construction" between different partners, and it challenges all those involved to reconsider received wisdoms. It is not alone in Thailand, but SLUSE is a part of a growing move to expose the ways in which environmental perceptions are framed, going further to encourage the elaboration of alternative environmental management practices that support socially just and sustainable livelihoods. 


\section{References}

Anderson, E. F.

1993. Plants and People of the Golden Triangle: Ethnobotany of the Hill Tribes of Northern Thailand.

Portland, OR: Dioscorides Press.

Benton, Ted. and Craib, Iain.

2001. Philosophy of Social Science: The Philosophical Foundations of Social Thought. New York: Palgrave.

Bryant, Raymond L.

1992. Political Ecology: An Emerging Research Agenda in Third World Studies. Political Geography 11 (1), 12-36.

Bryant, Raymond. L.

1997. "Beyond the impasse: the power of political ecology in Third World environmental research." Area 29 (1): 5-19.

Buch-Hansen, Mogens.

2001. Is Sustainable Agriculture in Thailand Feasible? Journal of Sustainable Agriculture. 18 (2/3), 137 - 160.

Buch-Hansen, Mogens.

2003. Viable livelihoods for small-scale farmers with globalisation of Thailand's agricultural resources? Paper presented at the SLUSE Land Use Conference, Copenhagen.

Bunchee, S. and Anecksamphan C.

1993. Sustaining soil organic matter for upland rice production in northern Thailand. In Soil Organic Matter Dynamics and Sustainability of Tropical Agriculture. Mulongoy, K and Merck R (eds.) pp 155-161. London: John Wiley \& Sons Ltd.

Carrere R and Larry Lohmann.

1996. Pulping the South: Industrial Tree Plantations and the World Paper Economy. London: Zed.

Chuntanaparb, L and Wood H. I.

1986. Management of Degraded Forest Land in Thailand. Bangkok: Kasetsart University Press.

Collins, Wanda W. and Calvin O Qualset.

1998. Biodiversity in Agroecosystems. Washington DC.: CRC Press.

Dechalert, Preecha. 1999. NGOs, advocacy and popular protest: a case study of Thailand. International Working Paper 6. London School of Economics: Centre for Civil Society.

Dixon, Chris.

1999. The Thai economy: uneven development and internationalisation. London: Routledge.

Falvey, L.

2000. Thai Agriculture: Golden Cradle of Millennia. Bangkok: Kasetsart University Press.

Feeny, David.

1988. Agricultural Expansion and Forest Depletion in Thailand 1900-1975. In World Deforestation in the Twentieth Century. Richard, J. F. and Tucker R. P. (eds.). Durham: Duke University Press.

Fischer, Frank

2001. Citizens, Experts, and the Environment: The Politics of Local Knowledge. Durham, NC: Duke University Press.

Forsyth, Timothy J.

2003. Critical Political Ecology. The Politics of Environmental Science. London: Routledge.

Ganjanapan, Anan. 
1996. The politics of environment in northern Thailand: ethnicity and highland development programmes. In Seeing Forests for Trees: Environment and Environmentalism in Thailand. Phillip Hirsch (ed). pp202-222. Chinag Mai: Silkworm Books.

Ganjanapan, Anan (ed).

2000. Community Dynamism in Natural Resource Management: Paradigms and Policies. Bangkok: Thailand Research Fund.

Ganjanapan, Anan, Chalardchai Ramitanond, and Santita Ganjanapan.

1993. Community Forests in Thailand: Development Alternatives (in Thai). Community Forests in Northern Thailand (vol. 2). Bangkok: Local Development Institute

Gardner, S, and P. Sidisunthorn et. al.

2000. A Field Guide to Forest Trees of Northern Thailand. Bangkok, Kobfai Publishing Project.

Hirsch, Philip.

1993. Political Economy of Environment in Thailand. Manila: Journal of Contemporary Asia Publishers.

Hirsch, Philip.

1996a. Environment and environmentalism in Thailand: material and ideological bases. In. Seeing Forests for Trees: Environment and Environmentalism in Thailand. Hirsch, Philip (ed.) 15-36. Chinag Mai, Silkworm Books.

Hirsch, Philip (ed.).

1996b. Seeing Forests for Trees: Environment and Environmentalism in Thailand. Chiang Mai: Silkworm Books.

Holmberg, G.

1996. Local forest products in northern Thailand: case study on a Lahu village. FORTROP 96: International Conference on Tropical Forestry in the 21st Century.

IRN, 2002.

International Rivers Network Pak Mun campaign. http://www.irn.org/programs/pakmun

Kittampon, Ampon and Nabangchang, Orapan.

2001. The Grounds for Public Intervention in the Agricultural Sector in the Thailand. Manuscript.

Lohmann, Larry.

1998. Land, People and Forest Colonization in Thailand. In The Struggle for Land and the Fate of Forests. Colchester, Marcus and Lohmann Larry (eds.). London: Zed Books.

Ministry of Agriculture \& Co-operatives, Thailand.

2002. A Synopsis of Sustainable Agriculture. Bangkok: Ministry of Agriculture and Cooperatives.

Muscat, R.J.

1994. The Fifth Tiger: a study of Thai development policy. Helsinki, Finland: United Nations University Press.

Nabangchang, Orapan.

2001. Agricultural Production and Sustainable Use of Land and Soil Resource of Thailand: The Balance between Economics and Environmental Concerns. Manuscript.

Panayotou, Theodore and Chartchai Parasuk.

1990. Land and forest: projecting demand and managing encroachment. In The 1990 TDRI Year-End Conference: Industrializing Thailand and its impact on the environment, Session: Natural resources for the future. Chon Buri, Ambassador City Jomtien.

O'Riordan, T. (ed.)

2000. Environmental Science for Environmental Management. London: Prentice Hall.

Phongpaichit, Pasuk and Chris Baker.

1999. Thailand: economy and politics. Kuala Lumpur: Oxford University Press. 
Preechapanya, P.

1984. Soil and water losses from agro-forestry systems: A case study of coffee plantation under hill evergreen forest at Doi Pui, Chiang Mai (in Thai). M.Sc. thesis, Kasetsart University, Bangkok.

Putjaroon, W and Pongboon K.

1987. Amount of runoff and soil losses from various land use sampling plots in Sakolnakorn Province, Thailand. In Forest hydrology and watershed management. IAHS Publication 167, pp231-238. Wallingford, UK: Institute of Hydrology.

Rigg, Jonathan (ed.)

1995. Counting the Costs of Economic Growth and Environmental Change in Thailand. Singapore: Institute of Southeast Asian Studies.

Samapuddi, K and Suvanakorn P.

1962. A study on the effect of shifting cultivation on forest soils. Technical Report no 51. Bangkok: Royal Forest Department.

Samran, S.

1984. Rainfall erositivity factor in universal soil loss equation for mountainous areas of northern Thailand (in Thai). M.Sc. thesis, Kasetsart University, Bangkok.

Sato, J.

1998. The political economy of buffer zone management: a case study from western Thailand. In Victor, M (ed.) Community forestry at a crossroad: reflections and future directions in the development of community forestry. Proceedings of an international seminar. Pp 87-99. Bangkok: RECOFTC.

Sukawong, Somsak.

2003. Tropical Forest: Value of Biodiversity. In Resource Base and Live Capital of Thai Society. Sanay Lamarik (ed). Bangkok: Thailand Research Fund.

Suksawang, S. 1991.

Impact of Selective Logging Systems on Water Yield on a small Tropical Watershed in Thailand. Ph.D. Dissertation, University of the Philippines, Los Banos.

Thabchumpon, Naruemon

2002. NGOs and Grassroots Participation in the Political Reform Process. In Reforming Thai Politics.

McCargo, Duncan (ed.). 183-199. Copenhagen: Nordic Institute of Asian Studies.

Tisdell, Clem.

1997. Biodiversity, Conservation and Sustainable Development. New Horizons in Environmental Economics.

Traynor, C., Sidthinat Prabudhanitasarn, Peter oksen, Suthinee Dontree, and C. Sarnaak.

2002. Problems of Sustainable Land Use and Natural Resource Management in a Community at Song Watershed, Phrae Province, Thailand. Bangkok: TUCED-SLUSE.

Vandergeest, Peter.

1996. Mapping Nature: Territorialization of Forest Rights in Thailand. Society and Natural Resources 9: 159175.

Walker, Andrew and Scoccimarro, M.

2001. Agricultural intensification and emerging water resource constraints: a case study from northern Thailand. International Symposium on Watershed Management: Towards New Principles and Practices. Chiang Mai International Centre.

World Bank.

2002. Globalization, Growth and Poverty. Building an Inclusive World Economy. Washington DC.: Oxford University Press/World Bank.

Yos Santasombat and Amar Siamwala.

1998. Ecological Crisis Knowledge and Critiques (in Thai). Bangkok: Kobfai. 
Zurcher, Sacha.

2005. Public participation in community forest policy in Thailand: The influence of academics as brokers. Danish Journal of Geography 105 (1): 77-88.

\begin{abstract}
Environmental science is shaped by the socio-political context in which it is produced. Environmental problems and explanations are context specific, and this article contributes to a critical political ecology by illustrating the changing relationship between conceptualisation of environmental problems and explanations of them, and the socio-political context in contemporary Thailand. During the 'development epoch' from the 1950s, both natural and social sciences became compartmentalised and the epistemology of environmental science became dominated by the demands of a growth economy and utilitarian values. The resulting impasse of conventional knowledge of natural resource management coincided with a socio-political and bureaucratic reform process pushed by various democratic movements. Together with a request for decentralisation and devolution of state power, these movements are also fighting for sustainable utilisation of natural resources, and sustainable agricultural practices. A precondition, however, for sustainable utilisation of natural resources is a change in conceptualisation and knowledge creation for resource management. The Sustainable Land Use and Natural Resource Management (SLUSE) collaboration offers alternative ways of creating knowledge for sustainable utilisation of natural resources, that aim to support the present socio-political reform process in Thailand.
\end{abstract}

Key Words: Thailand, natural resource management, transdisciplinarity

\title{
Resumé
}

Les sciences environnementales sont conditionnées par les contextes sociopolitiques dans lesquels elles sont produites. Les problèmes environnementaux et leurs explications sont spécifiques aux contextes dans lesquels ils sont formulés. Cet article contribue à une approche critique de l'écologie politique en illustrant les changements dans la conceptualisation des problèmes environnementaux et leurs explications suivant l'évolution du contexte sociopolitique contemporain de la Thaïlande. Depuis les années 1950 et la période dite de développement, les sciences naturelles et les sciences sociales ont été sectionnées et les sciences environnementales ont été mises au service de la croissance économique et d'autres considérations utilitaires. L’impasse, qui résulte d’un savoir conventionnel sur la gestion des ressources naturelles, coïncide avec un processus de réformes sociopolitiques et bureaucratiques poussé par différents mouvements démocratiques. Ces mouvements, associés à une volonté de décentralisation et de concession des pouvoirs de l'État, se battent pour une gestion durable des ressources naturelles et des pratiques agricoles respectueuses de l'environnement. Malgré cela, un changement de conceptualisation et l'éducation à la gestion des ressources naturelles sont des pré-conditions nécessaires à leur utilisation rationnalisée. Le programme SLUSE, collaboration qui a pour thème l'utilisation durable des terres et la gestion des ressources naturelles, offre des solutions alternatives pour l'éducation à une utilisation rationnelle des ressources et au soutien du processus de réformes sociopolitiques Thaïlandais.

Mots Clés: Thailande, gestion des ressources naturelles, $<<$ transdisciplinarité $>>$ 